South African business managers often have to handle questions, problems and even threats that concern the interface between politics and business, rather than pure business management issues. For this reason, two recent addresses about politics-and-business are reproduced as Interfaces, since these may be of interest to our readers, may give them some insight, or an argument which may prove useful, particularly when dealing with overseas business associates.

\section{South Africa in international perspective}

\author{
Jan S. Marais
}

Member of Parliament (Pinetown), Houses of Parliament, Parliament Street, Cape Town, South Africa

Address delivered at an economic seminar on South Africa on 20 June 1979 at Palm Springs, California, USA

Received 21 June 1979

South Africa . . . is it racist? YES!

Is there colour discrimination? YES!

And denial of basic human rights? YES!

But is there not then agonizing among South Africans about it? YES!

Are changes taking place? YES!

These five questions I posed as an introduction to a publication 'South Africa: International bone of contention'. It also contains an open letter to the President of the USA, Mr Carter, objecting to a sermon he delivered to us from Nigeria and inviting him to visit South Africa and have a look with his own eyes at the realities of life as they exist in South Africa today. (Copies obtainable from Kirkpatrick and Associates, 7th Floor, London House, 21 Loveday Street, Johannesburg 2001, South Africa. Tel. No. (011)836-6525.)

'The Bone' is one of the results of an address I delivered in the House of Parliament in Cape Town when I appealed for:

- The compilation and distribution of a publication, on massive scale, of comparative factual information about South Africa

- A campaign of stepped-up communication in South Africa among the various population groups and between South Africa and the international community
- A campaign for a free but truthful and 'balanced viewpoint Press' - in South Africa and internationally with reference to South Africa.

In all these categories, some progress is being made but obviously much remains to be done.

In my remarks today, I shall endeavour to project a 'balanced viewpoint' of our part of the world.

South Africans fully realize that you, as leaders, opinion-makers and investors, cannot and will not look in isolation at South Africa's economy, its mind-boggling mineral wealth, its expanding market and its enormous potential for practically every kind of business development.

Politics, internal and international, social conditions, neighbouring environment, military preparedness, even nuclear capabilities - all these and a lot of other factors will all contribute to making up your minds for you. I shall try to give you, very briefly, what I believe is a truthful perspective.

We have the same problems as other leading countries - ours are only racially, minority groups-wise, much more complex. Indeed, South Africa is acknowledged as the world's most complex plural society. Why do we say that? Because there are 4,2 million Whites; 2,3 million Coloureds; 727000 Asians; and 18,1 million Blacks, divided into four main groups and nine national units.

Among the Blacks, the languages spoken can be divided into four main groups, 23 sub-groups, numerous dialects. Most groups cannot converse with one another in their home language. As with language, cultural differences are great. For example, the Venda are South Afria's most homogeneous black ethnic group, yet they have 27 distinct tribes. In contrast to the 27 Venda tribes, there are 200 Zulu tribes.

The Whites speak two main languages - English and Afrikaans - also include a strong Jewish community as well as large immigrant communities such as Portuguese, Greeks, and Lebanese.

The plural mosaic is also found among the Asians: 65, $1 \%$ are Hindus; $20,6 \%$ are Moslems; 6,9\% Christians and Buddhists; and 7,4\% are classified 'other'.

The Coloureds - a people of mixed origin - speak either Afrikaans or English or both.

If we therefore, take a little longer than it took you as Americans to resolve the challenges of human relationships, there are at least basic reasons for this, quite apart from what some might describe, and what we acknowledge as our 'special sins and stupidities'.

Yes, we have committed, and are committing, practically every conceivable sin which you have committed, of course with certain different accents - for example, we never really had 'lynchings', and we did not eliminate, for all practical purposes, any of the indigenous or original natives we found on the land.

Trailing behind you in certain racial matters, now by about 10 years in my personal view, we are also changing; and the pace is accelerating.

We are also aiming at full human rights for all, complete elimination of colour as well as other forms of discrimination and equality of opportunity for all. But, remember our complex plural society - a fact we cannot wish away. Also remember the formulas tried in other 
plural societies: Scandinavia, where strife only ended after the single monarchy was split into three; Israel, and the Palestinian Arabs; India and Pakistan, where attempts at power-sharing were abandoned after more than a million people had lost their lives; Cyprus; the Nigerian Federation, where more than two and a half million Ibos died; Burundi, where 250000 were killed; Angola, where large numbers are still dying; and so many others in West,Central and East Africa, where intertribal strife is traditional; and even Britain and her Celtic regions; Scotland and Wales; and Northern Ireland.

Have you added up the millions who died, and are dying in these 'experiments' aiming at one man one vote in a unitary society? South Africans have looked at these gruesome events and at 'The History of Man' and found that dividing up into separate but equal and cooperating nationalities without domination of one by the other, is almost as old as man himself, and seems to work the best in complex plural societies, for example in Europe.

As recently as on the eve of World War II, colonial empires based in Europe controlled much of the world's land mass and two-thirds of its population. These have vanished. The total number of nation-states in the world has more than trebled to a total of over 160 . This can be described as one of the major political revolutions in the history of mankind.

In a nutshell - we aspire to the same lofty ideals as advocated by the world's greatest humanitarians, including your President Carter. But 'we do care about how many will die in the process'. We South Africans, Whites, Coloureds, Asians, and most Blacks, are also 'minorities' similar to those who have died and are dying. We do not know why we should be condemned for seeking solutions along the same lines as the unfolding world pattern.

\section{Policy objectives}

As a guideline for you as leaders, opinion makers and investors, or potential investors, tourists, or even immigrants, I hope, here are the basic policy objectives of South Africa:

\section{A Southern African Community or Constellation of Nations}

For some 20 years $I$ have been advocating that Southern Africa, that is not only South Africa, but also several other states in this region, should develop into a 'community of nations' co-operating to the fullest possible extent in all matters of mutual interest but on a basis of domination by the stronger or larger in numbers over any one of the various individual states, or groups aspiring towards national self-determination.

For instance, we should all co-operate in harnessing the waters in Southern Africa as has already been done at Cabora-Bassa and Kunene, generating the electricity, irrigating the land, growing the foodstuffs, extracting the minerals, converting and refining them, and marketing the wealth of all these products among ourselves and internationally.

We would co-operate in defence, finance, transport, pest-control - whenever mutual interests are involved. An umbrella body, representative of the various nations, would meet a number of times during the year under the guidance of an alternating President. There would be no features of domination inherent in the structure of this voluntary organization.

More specifically, in present day South Africa itself, we aim at independent homelands for the clearly definable and clearly different black nations on land more or less historically settled by them; and for the whites, coloureds and Asians a common homeland on a kind of 'canton' basis, not very different from the Swiss system. I know that the issue of the urban Blacks, many completely detribalized, has not been finally resolved. This matter is receiving the urgent attention of special committees of investigation. Maybe the final outcome will involve, at least partly, a 'city state' concept which is not unknown elsewhere.

\section{A united front with as many freedom-loving nations} as possible against Russian imperialism

We believe that we both have this common enemy and common challenge. We do not want to use this as a reason why you should be interested in us, but we believe that should we have to succumb to the onslaughts on our part of the world, you will follow within a relatively short space of time.

We are dedicated to non-aggression and we have no imperialistic motives whatsoever. On the contrary, our policies are all directed towards national selfdetermination of all those who aspire towards this ideal.

\section{International trade}

We could co-operate with, and trade with all those who are willing to do so with us, without interfering in any way in their domestic affairs, and we would expect this to be reciprocal. In this regard we are very pleased with our increased and increasing trade and cooperation with countries in Africa and certain Fifth World states such as Israel, Taiwan and many others.

I may add that among us, we possess of the most advanced scientific and technological know-how in the world, as well as of its most extensive and strategic mineral and other raw mineral resources. For instance, the oil from coal technology about which you all know.

We shall continue to pursue the ideal of trade and friendly cooperation with these nations; not forgetting our traditional trading partners in the rest of the world. Our 'stance' will be neutral. We are already a great trading nation ranking about 15 th in the world.

\section{International policies}

Internally, in South Africa, our accepted policy is to meet the political aspirations of all the groups now living there. We also aim at 'one man one vote', but not only once; and according to a formula or formulas where there will not be domination of the stronger or larger in number over any of the others. We shall continue aiming at a real economic growth rate target of more or less $6 \%$ average per annum, long-term, which should provide full employment and continued rising living standards. We shall continue aiming at an acceptable distribution of income among the various population groups in South Africa, based on the principles of increasing productivity, and merit, through education, training, job availability, and equality of opportunity.

We shall continue aiming at an acceptable distribution 
of wealth, that is, the 'economic cake', on the basis that this must be earned on merit; not on a basis of taking away from those others who have already achieved a good share. Our idea is to make the 'economic cake' itself bigger.

The recent Wiehahn and Riekert Reports with reference to Labour and Manpower and their acceptance by the government, are important manifestations of our objectives, and of the changes that are, evolutionarywise, ta-king place in South Africa.

\section{Total preparedness}

We believe in and have largely achieved 'total preparedness' against possible physical onslaughts against us on all fronts - military, production capabilities, economic and the dedication of our people. We shall continue to promote and maintain this ideal. We are happy with the progress being made. You might wish to read the new book 'South Africa? War? Revolution? Peace?', by Dr Lewis H. Gann and Peter Duignan of the Hoover Institute, Stanford University. They maintain that South Africa has become a young military giant that not even the super powers could bring to her knees.

\section{Free enterprise}

We believe in the free enterprise system - a free capitalistically oriented society but with full recognition of the social and strategic responsibilities of both the state and the private sectors.

In this regard we recognize that although we can keep on growing without the inflow of foreign capital, the achievement of our ideals will be much more difficult and will take a much longer time without such inflow of capital. I may also mention that our export potential can, and I believe will, play a vital role. We are therefore busy with, and shall continue to give our attention to, maintaining and further improving the traditionally 'favourable investment climate' in our country.

It was recently possible for us to reduce personal and corporate taxation and to liberate exchange control somewhat. We shall endeavour to continue making South Africa one of the most attractive investment areas in the world - a reputation it has already enjoyed for a very long time, and also a selfish concept of self-preservation. In this regard, I might refer to the Dallas Securities Investment Corporation Research Reports - Strategic Minerals of South Africa, a Key to Free World Economic Stability; and Relevant Risk Factors affecting South African Investments.

\section{How does South Africa figure today in the Southem African, African and world context?}

You are well aware of our role in bringing about peaceful solutions in Zimbabwe Rhodesia and South West Africa. These are tricky, but we believe that over a period of time, success will be achieved. There are, of course, clear indications that ethnicity, even after a democratic election, still prevails. I am here referring to the Rev. Ndabaningi Sithole's reaction to the recent Rhodesian election results.

Now let us also look at our factual position in the African context today: South Africa has only $4 \%$ of Africa's total area and $6 \%$ of its total population, yet it supplies over $50 \%$ of total electricity generated, has $74 \%$ of all electrified railroads and $45 \%$ of all telephones; and produces over $25 \%$ of the continent's total gross national product.

In Black Africa, food production is declining by $2 \%$ per capita per annum (with all the resultant hunger, misery and even starvation brought about by lowering living standards). Four out of five African countries cannot survive without food imports. In this grave situation, South Africa is the only food exporter in the entire continent. Further, food production in South Africa is rising by $5 \%$ per annum, and has been since $1960-$ a healthy figure that is double the population growth. South Africa, according to researcher Moshe Decter, has a 'flourishing and growing' trade (despite sanctions) with 19 Black African countries.

On an average day, four L-100 airfreight aircraft leave Johannesburg with cargo for Black Africa. Half of Zaire's copper exports and half of its food imports move through South Africa; $60 \%$ of goods passing through the port of Maputo in Mocambique goes to, or comes from South Africa. Zambia's major import trade partner is South Africa. Lesotho has six of its adult males working in South Africa for every one adult male who can find work in Lesotho.

Seventy percent of all secondary school teachers and four out of five medical doctors in Southern Africa, are in South Africa. Small wonder then, that enlightened black voices in South Africa are pleading against isolation and for further and faster satisfying of black aspirations through investments, stability and progress. In this way, as happened in the USA, Blacks will get a better deal more quickly.

At least 12 Black African nations are economically so dependent on South Africa that, according to the Argus African News Service, they would face economic ruin if a total embargo were enforced on South Africa.

In the international popularity polls, African states boycott us - but they continue to trade with and depend on us! We produce: $41 \%$ of all maize (corn), $32 \%$ of all sugar cane, $21 \%$ of all red meat, $20 \%$ of all potatoes, and $19 \%$ of all wheat on the African continent.

In education, literacy rate and upliftment of underdeveloped people, we lead Africa; in fact we lead the United Nations Organization (UNO) and the world.

In world context, with only $0,8 \%$ of the world surface $(0,07 \%$ arable) and only $0,5 \%$ of the world population, we in South Africa possess: $72 \%$ of its chromium reserves, $65 \%$ of its gold reserves, $60 \%$ of its platinum reserves, $50 \%$ of its manganese reserves, $50 \%$ of its vanadium reserves, $50 \%$ of its diamond reserves, and $25 \%$ of its uranium reserves, plus also a substantial percentage of practically every other known and essential mineral. This is remarkable by any standard.

It is rather ironic that the Good Lord chose to place most of the vital and critical materials of a modern, technological society in two major regions of the world, one of them is Southern Africa, including Zimbabwe Rhodesia, the other is the USSR. Perhaps in South Africa it was to compensate us for having placed on our shoulders also the world's most complex racial problem! The fact of the matter is that if the USSR would gain control of South Africa, they could literally hold the West 
hostage by denying it the things that they need - nickel, vanadium, platinum, chromium, etc. They could also, for instance, quadruple the price (if they choose to sell at all) in order to cause chaos and financial disruption in the West.

Finally, South Africans are watching with interest what seems like structural international power shifts - such as the emergence of a European power block, ultimately embracing some 250 million people under the predominant leadership of France and Germany, both with large interest in, and better knowledge of, the realities of Africa and South Africa than most other countries. Perhaps their attitudes might be even if only below the surface, at least more understanding and sympathetic than that of most other countries.

\section{But why is South Africa singled out for special con- demnation?}

There are a number of complex reasons for South Africa's present position:

- South Africa is the 'key' to world domination through Russian imperialism. As indicated, apart from our strategic physical situation, our resources,together with that of the USSR will give them a virtual monopoly of some of the most vital and scarcest minerals and other raw materials required to keep the economy of the West going.

- Our racial complexities and, what I believe, excessive and unnecessary legislation which appeared necessary at one time to establish a framework for peaceful unfoldment of acceptable living conditions for all, but which also created in the interim innumerable racial incidents. The USSR perceived and grasped this opportunity of exploiting this situation through a cleverly devised 'psychological onslaught' on us, especially through the media, churches and a large number of 'do-good' organizations on a scale the world has never witnessed before.

Remember, the Russians are masters at this game. Is the 'Berlin Wall' not an example - the strategy of keeping people in the dark about the truth? East Berliners are not to know of the better and happier life on the other side. That is why they campaign for isolating South Africa. Communication with South Africa, and more people coming to us to see with their own eyes, will explode their carefully laid plan of hypocracy.

- The United Nations have become dominated by the large number of Third World countries, insulted by South African race politics and therefore anti-South African. The Super Power are competing for the favour and support of these countries, and in the process, often apply double standards.

\section{South Africans are 'no innocent babies' either!}

Of course, not all those against us are Russian imperialists; some really mean well. Of course, as I said in the begining, we are not 'innocent babies' either. I do not want you to get the impression of any 'holier than thou' stance on the part of South Africa. However, please forgive us for being a little disillusioned.

Apart from the 'treatment' we ourselves experience from your Government, we have also looked at Taiwan, South Korea, the Phillipines, Zimbabwe Rhodesia - we feel your Government has also let them down.

We owe you nothing! We have never let you down, or campaigned against you, or accepted a cent, or a nickel, in foreign aid from you. On the contrary, we have done everthing in our power to maintain good relations with you. We, or at least most of us, believe that your Government's proscriptive treatment of our Government is positively suicidal. We hope you will tell your Senators and Congressmen so. We hope you will actively campaign to restore normal relations between our two countries. We believe we logically and naturally belong together.

\section{A vision for the future}

Short-term, it can be expected that the world propaganda campaign against South Africa will accelerate dramatically. In-depth analysis, however, indicates that in an important sense we are beginning to win the psychological onslaught against us. Never before have so many people in so many other countries, leaders as well as the general public, asked so many questions about the realities and the 'truth' in South Africa. This is very good and goes beyond political expediency. The more we are 'winning', the more dramatic and fanatical the onslaughts by our enemies will be - in a certain sense manifestation of our success.

Eyes are opening, in more and more knowledgeable circles, that apart from perhaps Saudi Arabia, the world's biggest single plum today is South Africa, the strategic anchor to a continent, the world's largest mineral treasure chest and the guardian of the West's oil shipping lanes. Changing attitudes and practices in South Africa are taking place and are expected to accelerate, complementing a 'rethink' about us by increasing numbers of well-meaning and honest people around the world.

I foresee a flourishing Southern African Community of Nations emerging slowly but surely over the next two decades - some 100 million people ultimately; of which some 55 million in the present South African area - free of discrimination not based on merit; not only on colour, but also with reference to birth, age and sex; South Africa being an important source of finance and technological, administrative and managerial know-how, ensuring proper and rising living standards for the larger community.

In the political sense, I believe there will be national self-determination on issues where controversy, domination and exploitation could occur while on the economic front and in matters of common interest such as defence, transport and agriculture, there would be the fullest cooperation - a model as good as or better than the one that now is slowly emerging in Europe.

From the viewpoint of investors, tourists and immigrants, I foresee a 'scramble' to 'get in'! First-comers will obviously enjoy the superior fruits of their confidence and their foresight in being 'first'.

I urge you to start thinking of Southern Africa as the 'treasure chest' that it really is, instead of seeing it as a menacing powder keg! I urge you to get in; and to get involved! I believe that it will be very rewarding! 